\title{
Activity of some enzymes, participating in nitrogen compounds transformation in chernozem, polluted by fluorine compounds
}

\author{
Vitalii Gryshko \\ Plant Physiology and Soils Biology Department, Kryvyi Rig Botanical Garden NAS of Ukraine, 50, Marshaka str., \\ Kryvyi Rig, 50089, Ukraine, e-mail: vit.grishko@ rambler.ru
}

Keywords: soil enzymes, fluorine contamination, soil biology

SUMMARY

\begin{abstract}
Contamination of chernozem by fluorine compounds variously affects those enzymes (urease, asparaginase, glutaminase, arginase, amidase), which takes part in the metabolism of nitrogen-bearing organic compounds. In broken soils the inhibited desaminisations is stronger, than enzymatic hydrolysis of asparagine and arginine. The features of seasonal dynamics of change activity of urease and correlation dependence of its activity from some physical and chemical soils properties are described. These tendencies well comport with the results of model experiments. At minimum HF influence there is inhibition of processes of monohydrocarboxylic acids desaminisation, hydrolytic breaking up of arginine and glutamine. By a side with this there is activating of urea and asparagine breaking up processes on the initial stages of toxicant influence. The study of kinetics of process of urea enzymatic hydrolysis in chernozem at the different level of HF influence showed changes of initial and maximal velocity of enzymatic reaction, and also Michaelis-Menten constant.
\end{abstract}

\section{INTRODUCTION}

Soil enzymes are one of the active components of biological processes of organic matter transformation in soil. Presently soil biology deals with the actual problems in soils, among which the leading place is occupied by "soil biology and environment protection" (Zvyagincev, 2001). The latter one requires a special meaningfulness at the study of ecosystems functioning, formed in the large industrial regions of Ukraine with the great amounts of toxic compounds including fluorides (Pomazkina et al., 2005; Shelepova-Potatueva, 2003). The influence of fluorines compounds on composition of basic physiological groups of soils microorganisms of chernozems and forest soils was studied by several scientists (Evdokimova et al., 2005; Gryshko, 1998a; Gryshko, 1998b). In spite of it, we haven't enough information about the soil enzymes and their function, which also enter in the complement of organic matter of soil. It is thus necessary to take into account that most soil enzymes have microbial origination and actively participate in the biogeochemical streams of chemical elements in ecosystems and landscapes. The study of these processes presents the special actuality for understanding the specificity of the biogeochemical functions of the broken soil concerning the mobilization and movement of elements in food chains (plants - animals - microorganisms). Therefore researches were conducted on features of enzymes functioning as ammonifying microorganisms that participate in the processes of nitrogen-bearing organic matters transformation in soil polluted by fluorine compounds (Evdokimova, 2005; Gryshko, 1999).

\section{MATERIALS AND METHODS}

The objects of theresearches were the broken soils which were formed at different distances from the source of fluorine emissions (Zaporizhzha aluminum combine), chernozem southern (at a distance more than $40 \mathrm{~km}$ from the source of emissions). In model experiments chernozem soil was used, which was fumigated by hydrofluoric acid in concentrations $0.02 ; 0.2$ and $2.0 \mathrm{mg}$ of $\mathrm{HF} / \mathrm{M}^{3}$. The activities of asparaginase (EC 3.5.1.1), glutaminase (EC 3.5.1.2), amidase (EC 3.5.1.4), urease (EC 3.5.1.5) and arginase (EC 3.5.3.1) were determined on 10, 20 and 30 days of toxicant's influence by the generally accepted methods (Khaziev, 1990). Determination of some kinetic indices of enzymatic reaction, catalyzed by urease, was conducted according to Khaziev F.H. (Khaziev, 1990).

\section{RESULTS AND DISCUSSION}

In technogenic-broken landscapes in composition of vegetable tailings and microbial cells in urban soils contains large amounts of proteins, amino acid and other nitrogen-bearings compounds. In further transformation of these matters play a considerable role, because they are present in soil proteolytic and desaminating enzymes. As a result of the processes of the successive proteolytic breaking up to amino acid and disintegration under the action of amidohydrolases (asparaginase, glutaminase, urease and arginase) and also desaminases (amidases) nitrogen of proteins mineralizated these forms are accessible for higher plants.

The research of soils amidohydrolases and desaminases activity showed that in the epiphase of the broken soil $(0-10 \mathrm{~cm})$ in strong contamination zone, which, was showed in a previous works, th degree of pollutants are the fluorides (Gryshko, 1997), there is substantial inhibition of all of investigated enzymes functioning (table. 1). 
While the activity of amidase and arginase went down in the largest degree, it is more than on $80 \%$, the intensity of the processes of the asparagine hydrolytic breaking up in a zonal soil went down only $27 \%$.

Table 1.

Asparaginase, arginase and amidase activity in soils, polluted by fluorine-containing extras, $\mathrm{mg} \mathrm{N}^{-\mathrm{NH}_{4}}{ }^{+} / \mathrm{g}$ soil for $24 \mathrm{~h}$

\begin{tabular}{|c|c|c|c|c|c|c|c|}
\hline \multirow{2}{*}{$\begin{array}{c}\text { Zone of } \\
\text { contamination }\end{array}$} & \multirow{2}{*}{$\begin{array}{l}\text { Sampling } \\
\text { depth, cm }\end{array}$} & \multicolumn{2}{|c|}{ Asparaginase } & \multicolumn{2}{|c|}{ Amidase } & \multicolumn{2}{|c|}{ Arginase } \\
\hline & & $\mathrm{M} \pm \mathrm{m}$ & $t_{\mathrm{st}}$ & $\mathrm{M} \pm \mathrm{m}$ & $t_{\mathrm{st}}$ & $\mathrm{M} \pm \mathrm{m}$ & $\mathrm{t}_{\mathrm{st}}$ \\
\hline \multirow[t]{3}{*}{ Strong } & $0-10$ & $0.54 \pm 0.012$ & 4.8 & $0.33 \pm 0.02$ & 14.8 & $0.04 \pm 0.001$ & 45.1 \\
\hline & $20-30$ & $1.16 \pm 0.062$ & 4.6 & $0.5 \pm 0.013$ & 19.7 & $0.06 \pm 0.005$ & 18.9 \\
\hline & $40-50$ & $0.21 \pm 0.01$ & 11.3 & $0.57 \pm 0.009$ & 5.4 & $0.05 \pm 0.001$ & 39.9 \\
\hline \multirow[t]{3}{*}{ Middle } & $0-10$ & $0.64 \pm 0.008$ & 2.5 & $0.35 \pm 0.008$ & 67.8 & $0.06 \pm 0.003$ & 33.0 \\
\hline & $20-30$ & $1.11 \pm 0.03$ & 5.1 & $0.57 \pm 0.014$ & 15.2 & $0.08 \pm 0.01$ & 7.5 \\
\hline & $40-50$ & $0.21 \pm 0.01$ & 11.3 & $0.54 \pm 0.007$ & 6.9 & $0.12 \pm 0.016$ & 0.5 \\
\hline \multirow[t]{3}{*}{ Typical chernozem } & $0-10$ & $0.74 \pm 0.04$ & - & $0.9 \pm 0.033$ & - & $0.17 \pm 0.002$ & - \\
\hline & $20-30$ & $0.75 \pm 0.063$ & - & $0.85 \pm 0.012$ & - & $0.15 \pm 0.001$ & - \\
\hline & $40-50$ & $0.68 \pm 0.04$ & - & $0.72 \pm 0.026$ & - & $0.13 \pm 0.001$ & - \\
\hline
\end{tabular}

In the underlayers of soil $(20-30 \mathrm{~cm})$ of all of zones of contamination the fluorine-containing industrial extract of the Zaporizhzha aluminum combine there is a decline in fluorine concentration and, as a result to a lesser degree in its inhibitional action on the biochemical processes of nitrogenorganic compounds transformation shows up. So, arginase and amidase activity are still statistically for certain below in certain case than in the analogical layer of the typical chernozem, but in 1.5 times higher, than in an epiphase. The same dependence is observed in the layer of $30-40 \mathrm{~cm}$. Another tendency is characteristic for other investigated amidohydrolases. So, asparaginase activity increased in certain case more than $40 \%$ at the decline of level of fluorine maintenance in soil(Table. 1$)$.

The study of seasonal dynamics of urease activity in chernozem typical showed that the largest increase of activity (to $17.43 \mathrm{mg}$ of $\mathrm{NH}_{4}{ }^{+} / \mathrm{g}$ soil) is marked in June. In subsequent months there is its gradual decline to the minimum values in autumn (fig. 1). In the broken soils of areas of strong, middle and weak contamination there is diminishing of urease activity in May to $0.36 ; 1.21$ and $1.51 \mathrm{mg} \mathrm{of} \mathrm{NH}_{4}^{+} / \mathrm{g}$ soil, while in April the activity of enzyme was 1.56; 2.64 and $3.24 \mathrm{mg}$ of $\mathrm{NH}_{4}{ }^{+} / \mathrm{g}$ soil accordingly in soils of the indicated areas.

Figure 1. A seasonal dynamics of urease activity changes in soil of areas of different level of contamination, mg N-NH ${ }_{4}^{+} / \mathrm{g}$ soil for $24 \mathrm{~h}$

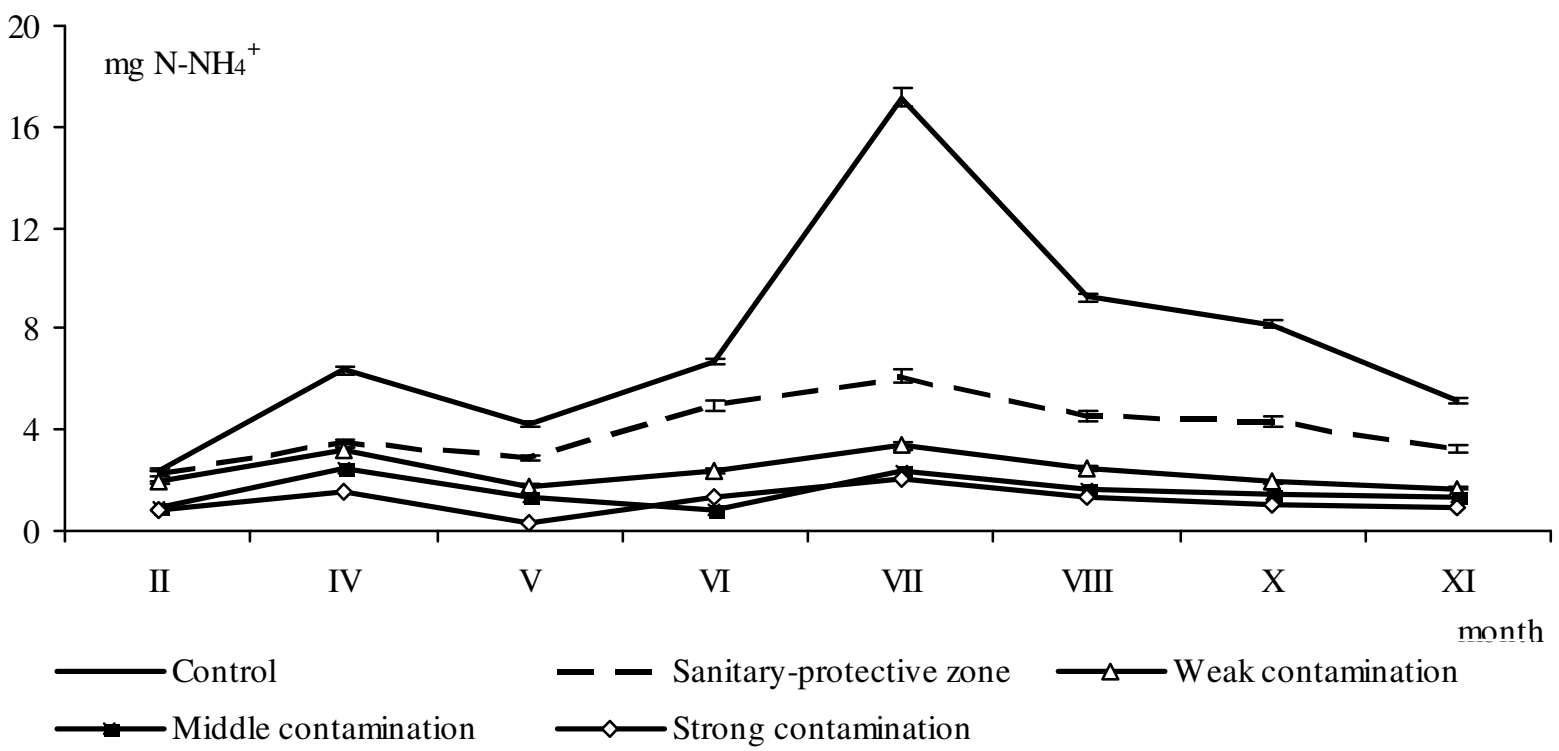

For the confirmation of the supposition that exactly fluor-containing emissions of enterprise are caused marked higher tendencies in change of biochemical processes of nitrogenorganic compounds mineralization, we executed model experiments on a typical chernozem, fumigation by hydrofluoric acid. It makes practically the half of all of fluor-containing extract falls into a category most toxic and reaction-active fluorine compounds.

The analysis of the received experimental data testifies that already in the case of minimum concentration of hydrofluoric acid there are two tendencies of activity changes of the enzymes studied (Table 2, figure. 2). 
The first one is related to the reduction of enzymatic activity and characteristic for amidase, glutaminase and arginase. A considerable inhibition of enzymatic activity at the initial stage of toxicant action is marked for amidase (more than $25 \%$ in relation to control), while for glutaminase and arginase -20 and $8 \%$ respectively.

Table 2.

Asparaginase, glutaminase and amidase activity in chernozem usual, fumigated by hydrofluoric acid, $\mathrm{mg} \mathrm{N}^{-\mathrm{NH}_{4}} / \mathrm{g}$ soil for $24 \mathrm{~h}$

\begin{tabular}{|l|c|c|c|c|c|c|}
\hline \multirow{2}{*}{ Variant of experiment } & \multicolumn{2}{|c|}{ Amidase } & \multicolumn{2}{c|}{ Glutaminase } & \multicolumn{2}{c|}{ Asparaginase } \\
\cline { 2 - 7 } & $\mathrm{M} \pm \mathrm{m}$ & $\mathrm{t}_{\mathrm{st}}$ & $\mathrm{M} \pm \mathrm{m}$ & $\mathrm{t}_{\mathrm{st}}$ & $\mathrm{M} \pm \mathrm{m}$ & $\mathrm{t}_{\mathrm{st}}$ \\
\hline \hline Control & $3.11 \pm 0.014$ & - & $0.046 \pm 0.001$ & - & $0.50 \pm 0.003$ & - \\
\hline $0.02 \mathrm{mg} \mathrm{HF} / \mathrm{m}^{3} 10$ days & $2.28 \pm 0.021$ & 33.0 & $0.037 \pm 0.001$ & 26.2 & $0.82 \pm 0.004$ & 63.0 \\
\hline $0.2 \mathrm{mg} \mathrm{HF} / \mathrm{m}^{3} 10$ days & $1.87 \pm 0.01$ & 76.2 & $0.032 \pm 0.0002$ & 43.2 & $0.79 \pm 0.002$ & 72.2 \\
\hline $2.0 \mathrm{mg} \mathrm{HF} / \mathrm{m}^{3} 10$ days & $1.61 \pm 0.028$ & 47.2 & $0.026 \pm 0.0005$ & 56.0 & $0.69 \pm 0.002$ & 51.5 \\
\hline $0.02 \mathrm{mg} \mathrm{HF} / \mathrm{m}^{3} 20$ days & $1.6 \pm 0.01$ & 88.9 & $0.035 \pm 0.001$ & 23.3 & $0.67 \pm 0.002$ & 46.1 \\
\hline $0.2 \mathrm{mg} \mathrm{HF} / \mathrm{m}^{3} 20$ days & $1.05 \pm 0.022$ & 78.8 & $0.027 \pm 0.0002$ & 51.9 & $0.65 \pm 0.003$ & 32.8 \\
\hline $2.0 \mathrm{mg} \mathrm{HF} / \mathrm{m}^{3} 20$ days & $0.83 \pm 0.05$ & 46.7 & $0.021 \pm 0.003$ & 72.3 & $0.62 \pm 0.003$ & 28.4 \\
\hline $0.02 \mathrm{mg} \mathrm{HF} / \mathrm{m}^{3} 30$ days & $1.17 \pm 0.02$ & 88.5 & $0.029 \pm 0.001$ & 50.4 & $0.60 \pm 0.002$ & 26.41 \\
\hline $0.2 \mathrm{mg} \mathrm{HF} / \mathrm{m}^{3} 30$ days & $0.53 \pm 0.019$ & 109.7 & $0.022 \pm 0.001$ & 65.9 & $0.56 \pm 0.003$ & 14.7 \\
\hline $2.0 \mathrm{mg} \mathrm{HF} / \mathrm{m}^{3} 30$ days & $0.33 \pm 0.034$ & 75.0 & $0.016 \pm 0.0003$ & 67.3 & $0.45 \pm 0.003$ & 10.9 \\
\hline
\end{tabular}

With the increase of toxicant concentration and duration of its influence there is more considerable pressure of processes of transformation of nitrogencontent organic compounds, catalyzed by glutaminase, amidase and arginase. Already on the 20 days of chernozem usual fumigation by hydrofluoric acid in a minimum concentration, amidase activity went down to $40 \%$ in relation to control (Table. 2), while arginase - to $18 \%$ (fig. 2 , b). The maximal decrease of enzymatic activity was observed with 30 days of toxicants influence. So, during in a typical chernozem the usual fumigation of increasing concentrations of toxicants $(0.02 ; 0.2 \mathrm{and} 2.0 \mathrm{mg}$ of $\mathrm{HF} / \mathrm{m}^{3}$ ) amidase activity went down in relation to control more than 50, 60 and $80 \%$ accordingly.

Figure 2. Urease (a) and asparaginase (b) activity in typical chernozem at action of hydrofluoric acid, mg N-NH ${ }_{4}^{+} / g$ soil for 24 h, 1 - 10 days, 2 - 20 days and 3 - 30 days
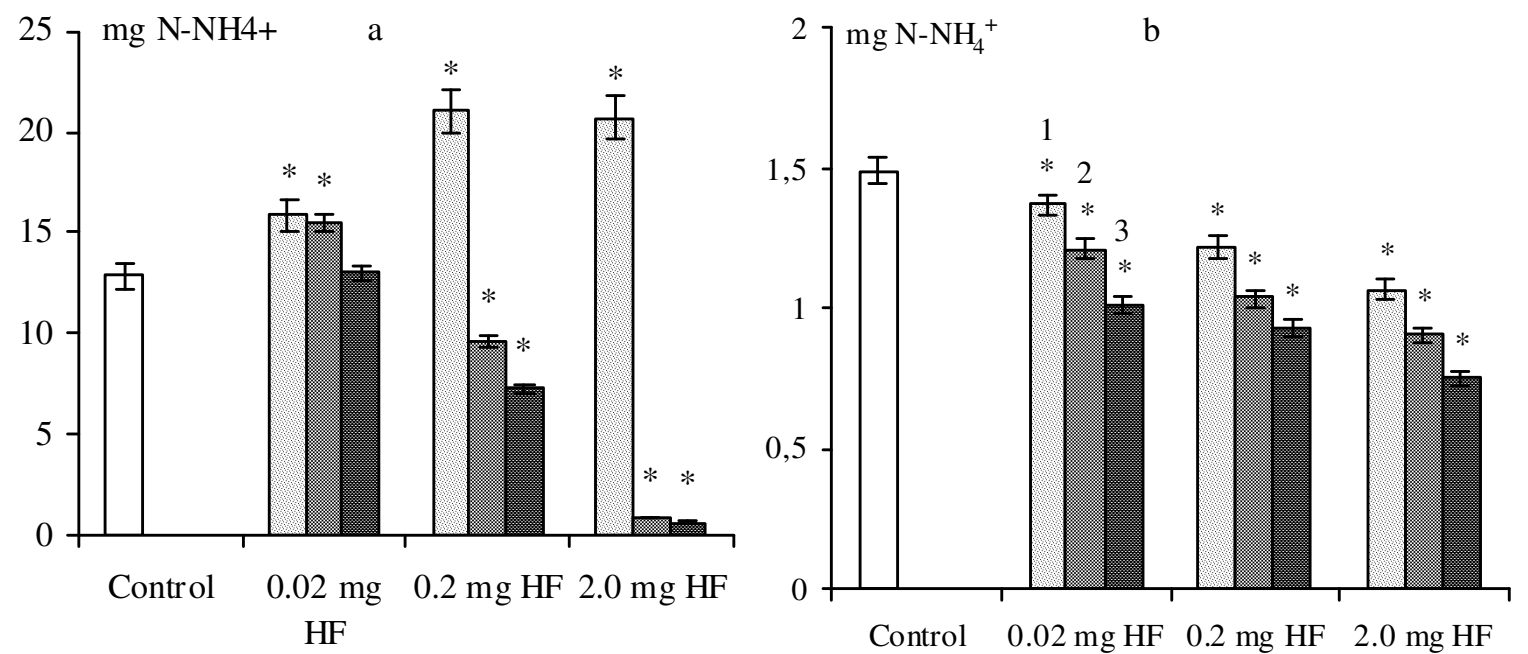

The second tendency is represented by the increase of urease and asparaginase activity at a certain level of toxicant receipt in soil. So, the insignificant toxicants receipt, which is observed during fumigation of a typical chernozem during 20 days in a minimum concentration, resulted in the increase of urease activity to $60 \%$ in relation to control, while middle and maximal concentrations - to its decline more than 20 and $40 \%$ accordingly (fig. 2, a). Analogical tendency was observed us and for asparaginase with that only by a difference, that enzymatic activity inhibition takes place at the action of hydrofluoric acid in a maximal concentration during 30 days (Table. 2).

For explaining the higher tendencies of results, in our opinion, it is necessary to take into account the circumstances that (to the decline of enzyme activity) can bring not only an inhibition action over the fluorine but also the increase of soils acidity, which takes place at a hydrofluoric acid receipt. From data of F.Khaziev, by an optimum reaction for urease there is $\mathrm{pH}$ 6.5-7.0 in soil, and in acid and alkaline environments urease displays weak activity (Khaziev, 1982). The increase of enzyme activity, obviously, can be explained by the fact that fluorine takes part in the processes of the thin biochemical adjusting of urease and asparaginase functions at the 
level of conformation changes of proteins quaternary structure. It can show up in the change of enzymatic reaction kinetic descriptions.

For finding out the fluorine influence on flowing of reaction, catalyzed by urease, the kinetic indices of this process were proved by us, in particular, the maximum speed of reaction. At the research of features of enzymatic process the kinetics of optimum interval of display was set, in which the speed of reaction was at maximal level and answers the stage of its "initial velocity". In the model experiment of soil the optimum displays of initial velocity time for measuring the reaction catalyzed by urease were proved (Table. 3). The curves obtained for all variants of experience have maximums at 15 minutes of incubation. Exposition set by experimental way was used for $\mathrm{V}_{\max }$ determination.

Table 3.

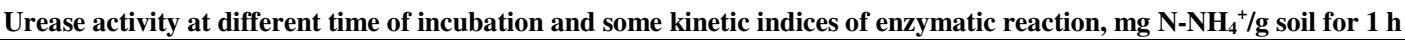

\begin{tabular}{|c|c|c|c|c|c|c|c|c|}
\hline \multirow{2}{*}{ Variant of experiment } & \multicolumn{6}{|c|}{ Incubation time } & \multirow[t]{2}{*}{$\mathrm{K}_{\mathrm{M}}, \mathrm{mol}$} & \multirow[t]{2}{*}{$\mathrm{V}_{\max }$} \\
\hline & $15 \mathrm{~min}$ & $30 \mathrm{~min}$ & $1 \mathrm{~h}$ & $3 \mathrm{~h}$ & $6 \mathrm{~h}$ & $24 \mathrm{~h}$ & & \\
\hline Control & 4.0 & 2.4 & 2.2 & 1.54 & 0.78 & 0.54 & 52.63 & 10.0 \\
\hline $0.02 \mathrm{mg} \mathrm{HF} / \mathrm{m}^{3} 10$ days & 5.6 & 3.6 & 3.1 & 2.07 & 1.26 & 0.66 & 58.82 & 10.0 \\
\hline $0.2 \mathrm{mg} \mathrm{HF} / \mathrm{m}^{3} 10$ days & 4.4 & 3.2 & 2.8 & 2.51 & 1.76 & 0.88 & 66.67 & 15.38 \\
\hline $2.0 \mathrm{mg} \mathrm{HF} / \mathrm{m}^{3} 10$ days & 4.4 & 4.2 & 3.4 & 2.64 & 2.02 & 0.86 & 45.45 & 13.89 \\
\hline $0.02 \mathrm{mg} \mathrm{HF} / \mathrm{m}^{3} 30$ days & 9.2 & 3.2 & 3.0 & 2.14 & 1.03 & 0.54 & 55.25 & 12.5 \\
\hline $0.2 \mathrm{mg} \mathrm{HF} / \mathrm{m}^{3} 30$ days & 8.0 & 3.6 & 3.2 & 2.3 & 1.1 & 0.6 & 30.30 & 11.11 \\
\hline $2.0 \mathrm{mg} \mathrm{HF} / \mathrm{m}^{3} 30$ days & 6.0 & 4.8 & 3.5 & 2.0 & 1.4 & 0.03 & 45.45 & 7.52 \\
\hline
\end{tabular}

Results in table 3. the dates prove that initial velocities of enzymatic reaction for soil fumigated by the different toxicants concentrations during 10 days were higher, than for a control variant, that well comports with the statistically reliable increase of enzymatic activity in these variants of experiments. After $24 \mathrm{~h}$ incubations initial velocity of enzymatic reaction in soil at the action of middle concentration of hydrofluoric acid went down 25 times, and high up 18 times as compared to control. In our opinion, such a considerable reduction of initial velocity of reaction for this temporal interval explaines the decline of urease activity.

The results of the research of substrate dependence of enzymatic reaction speed testify that urease substrate inhibition is observed during the substrate concentration $3.3 \mathrm{M}$ (Figure. 3). The executed calculation of $\mathrm{V}_{\max }$ and $\mathrm{K}_{\mathrm{m}}$ allows to establish that there is a substantial change at the action of hydrofluoric acid (Table. 3). So, already at the fumigations initial stage the increase of urease activity is accompanied by a growth $30-50 \%$ listed above indices. By a side with this more protracted influence or toxicants maximal concentration results in a decline by $25 \%$ values of $\mathrm{V}_{\max }$ and more than $10 \% \mathrm{~K}_{\mathrm{m}}$.

However, many explanation of changes of hydrolases activity in the broken soils is that the attendance of fluorine will not be quite liveable from the biological point of view. In fact, as it was shown by us before (Gryshko, 2009; Zvyagincev, 2001), forming of the broken soils is accompanied the substantial change of edaphic factors, which important for hydrolases functioning.

Table 4.

Coefficients of correlation $\left(R \pm m_{r}\right)$ between urease activity and some physical-chemical soils characteristics, $\mathbf{n}=24$

\begin{tabular}{|l|c|c|c|c|}
\hline $\begin{array}{l}\text { Zone } \\
\text { contamination }\end{array}$ & $\begin{array}{c}\text { Content of fluorine water- } \\
\text { soluble forms }\end{array}$ & Soils humidity & pH of water extractions & Humus \\
\hline \hline Strong & $-0.91 \pm 0.04$ & $+0.37 \pm 0.18$ & $+0.38 \pm 0.17$ & $+0.38 \pm 0.18$ \\
\hline Middle & $-0.87 \pm 0.05$ & $+0.45 \pm 0.16$ & $+0.56 \pm 0.14$ & $+0.44 \pm 0.16$ \\
\hline Weak & $-0.72 \pm 0.10$ & $+0.40 \pm 0.17$ & $-0.18 \pm 0.20$ & $+0.40 \pm 0.17$ \\
\hline $\begin{array}{l}\text { Sanitary-protective } \\
\text { zone of enterprise }\end{array}$ & $-0.32 \pm 0.18$ & $+0.39 \pm 0.17$ & $-0.31 \pm 0.18$ & $+0.28 \pm 0.19$ \\
\hline Typical chernozem & $+0.21 \pm 0.20$ & $+0.32 \pm 0.18$ & $+0.44 \pm 0.16$ \\
\hline
\end{tabular}

At first, soil enzymes are the products of biota vital functions (Pomazkina et al., 2005; Shelepova-Potatueva, 2003), therefore reducing the quantity of microorganism in the broken soils (Zvyagincev, 2001) can result a decrease in the amount of soil enzymes. Secondly, different level of materials containing of nitrogen, phosphorus, carbon and other compounds in soils which could play as substrates, inhibitors or activators of hydrolases, also explained the changes in enzymatic activity. So, for example, in soils, polluted by fluorides 1.5 and 1.7 times the maintenance of nitrogen and organic carbon diminishes to 20-30\% - phosphorus and potassium (Zvyagincev, 2001). Thirdly, an important value in the processes of immobilization and stabilizing of the broken soils enzymes have a capacity and cationic composition on soil complex, and could change the $\mathrm{pH}$ and others physical and chemical soils properties. In the earlier works (Gryshko1999; Zvyagincev, 2001) the change of these parameters was investigated in soils and are published. 
Figure 3. Substrate dependence of urease activity in coordinates at fumigation of chernozem usual by hydrofluoric acid 10 (A) and 30 (B) days

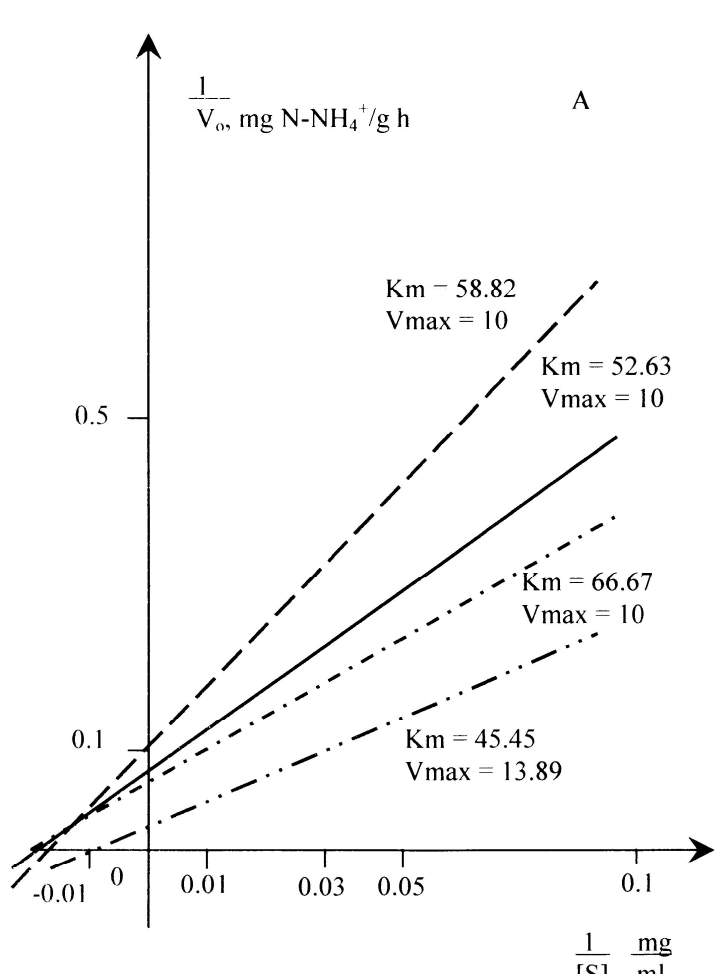

$\overline{[S]}, \overline{\mathrm{ml}}$

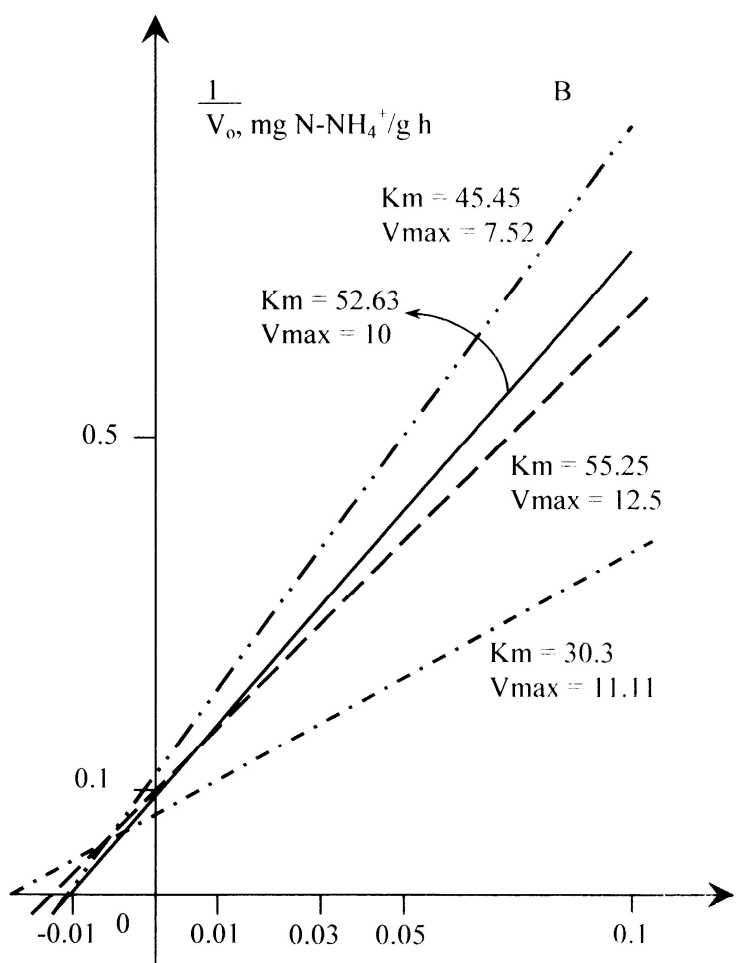

$\frac{1}{[S]} m g$

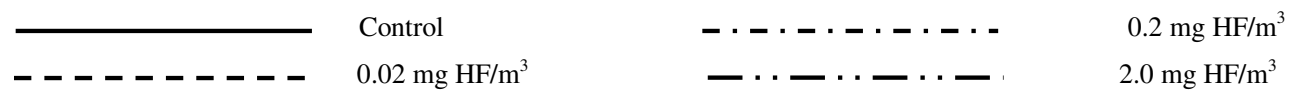

The executed correlation analysis allowed to set the presence of the another-directed connections of different strength between hydrolases activity and by some physical and chemical characteristics of polluted soils (table. 4). Although among the coefficients got of correlation the values prevail which indicates on weak and middle strength of influences, but for understanding the features and functions of hydrolases require more research.

\section{CONCLUSIONS}

In the research work the intensity of biochemical processes was investigated on the changes of enzimes activity of amidohydrolases (asparaginase, glutaminase, urease and arginase), and also desaminases (amidase) in chernozems polluted by fluorides, showed that fluorides variously affected on efficiency of enzymes functioning, taking part in metabolism of nitrogen-bearing organic compounds in soil. There is an inhibition of processes of desamination of monohydrocarboxylic acids amides even at the insignificant level of fluorine accumulation, hydrolytic breaking up of ornitine and glutamine. At the initial stages of toxicants influence is marked the activating of processes of urea and asparagines breaking up. With the increase of amount and time of action of fluorides there is more important effect on the process of biochemical transformation of urea than asparagines. The conducted study of kinetics of process of enzymatic hydrolysis of urea in soils at the different levels of hydrofluoric acid influences allowed to set substantial changes both initial and maximal speeds of enzymatic reaction.

\section{REFERENCES}

Evdokimova, G.A. - Zenova, I.V. - Mozgova, N.P. - Pereverzeva, V.N. (2005): Soil and soils biota in conditions of fluorine contamination. Kolsk Scientific Center RAS Publ., Apatity.

Gryshko, V.M. (1997): Fluorides in soils of geochemical technogenic anomaly. Reports of the National Academy of Sciences of Ukraine, 10: 132-137. 
Gryshko, V.M. (1998): Soils microbocenosis subject to contamination of fluorcontaining industrial emissions of acidic character. Microbiology, 3: 416-421.

Gryshko, V.M. (1998): Quantitative composition of some groups of soil microorganisms in ecotopes at fluoride contamination. Microbiological Journal, 2: 13-21.

Gryshko, V.M. (1999): Change of hydrolytic enzymes activity in soils polluted by fluorides. Reports of the National Academy of Sciences of Ukraine, 9: 194-200.

Gryshko, V.M. (2009): Functioning some amidohydrolases in chernozem polluted by fluorine compounds. Reports of the National Academy of Sciences of Ukraine, 12: 168-174.

Khaziev, F.H. (1982): System-ecological analysis of soils enzymatic activity. Nauka, Moscow.

Khaziev, F.H. (1990): Methods of soils enzymology. Nauka, Moscow.

Pomazkina, L.V. - Kotova, L.G. - Prokof'ev, A.Yu. - Lavrent'eva, A.S. - Aref'eva, I.A. (2005): The nitric mode in the different types of arable soils polluted by fluorides of aluminum production. Agrochemistry, 12: 59-66.

Shelepova, O.V. - Potatueva, Yu.A. (2003): Fluorine agroecological value. Agrochemistry, 9: 78-87.

Zvyagincev, D.G. (2001): Perspectives of soils biology development. MAKS Press, Moscow. 